\title{
Metabolic profiling, ADME pharmacokinetics, molecular docking studies and antibacterial potential of Phyllantus muellerianus leaves
}

\author{
Tolulope M. Obuotor ${ }^{1} \cdot$ Amos O. Kolawole ${ }^{1}$. Oladayo E. Apalowo ${ }^{2}$ (I) $\cdot$ Adio J. Akamo ${ }^{3}$
}

Received: 29 May 2021 / Accepted: 27 August 2021

(c) Institute of Korean Medicine, Kyung Hee University 2021

\begin{abstract}
Global increase in the level of antimicrobial resistance among bacterial pathogens has prompted the search for alternative treatment from medicinal plants. Phyllantus muellerianus leaves has been used traditionally against microorganisms of medical importance, hence the need to evaluate the pharmacological pathways and mode of actions using in vitro and in silico approaches. Clinical isolates of eight (8) microorganisms associated with urinary tract infections were obtained and identified using morphological and biochemical methods. Phyllantus muellerianus leaves were extracted and purified by solvent partitioning. Ethyl acetate fraction of PM had the highest yield and zone diameter range from $13.5 \pm 1.00$ to $28 \pm 1.53 \mathrm{~mm}$. The rate of protein leakage per time interval of Staphylococcus aureus increased from $9.29 \mu \mathrm{g} / \mathrm{ml}$ at $0 \mathrm{~min}$ to $17.43 \mu \mathrm{g} / \mathrm{ml}$ at $120 \mathrm{~min}$ while leakage in Candida albicans also increased from $8.57 \mu \mathrm{g} / \mathrm{ml}$ at $0 \mathrm{~min}$ to $70.43 \mu \mathrm{g} / \mathrm{ml}$ at $120 \mathrm{~min}$. GCMS fingerprints, pharmacodynamics and pharmacokinetic studies revealed the active agent as quindoline, an azaindole and isotere of indoles having a binding energy of $-9.1 \mathrm{kcal} / \mathrm{mol}$. Analyses of the structural and atomic orientations of quindoline, and superimposition on ciprofloxacin, a common antibiotic revealed an interesting comparison, effecting a stronger binding affinity of Quindoline-HMG-CoA complex.
\end{abstract}

Keywords Phyllantus muellerianus $\cdot$ Quindoline $\cdot$ Ciprofloxacin $\cdot$ Docking $\cdot$ HMG-CoA

\section{Introduction}

P. muellerianus is a widespread small plant that grows in the tropical region of West Africa. It is often found throughout the season in the forest areas with canopy-forming leaves. It belongs to the family Euphobiaceae and possesses fruits that are copious panicles of small red, shining berries that

Oladayo E. Apalowo

apalowooladayo@gmail.com

Tolulope M. Obuotor

obuotortm@funaab.edu.ng

Amos O. Kolawole

kolawoleamos2014@gmail.com

Adio J. Akamo

akamoaj@funaab.edu.ng

1 Department of Microbiology, College of Biosciences, Federal University of Agriculture, Abeokuta, Nigeria

2 Department of Biochemistry and Molecular Biology, Obafemi Awolowo University, Ile - Ife, Nigeria

3 Department of Biochemistry, College of Biosciences, Federal University of Agriculture, Abeokuta, Nigeria eventually turn black (Doughari and Sunday 2008). P. muellerianus has been used as an herbal remedy in many parts of the world. Fowler 2006 stated that the potency of this plant has been observed in Guinea, Ghana, Sierra Leone, Nigeria and other parts of Africa to assist women undergoing labour, to treat chronic dysentery, eruptive fever and eye infections and skin diseases (Fowler 2006). The fresh leaves can also be crushed and applied to wounds and the decoction used as purgative, for bronchitis and for relieving urethral discharges (Fowler 2006; Siram et al. 2004).

The qualitative analysis and the quantitative estimation of the phytochemical properties of $P$. muellerianus have been reported by Awomukwu et al. 2014 who stated that $P$. muellerianus possesses alkaloids, tannins and flavonoids, saponins and phenols both in the leaves, stem barks and roots (Awomukwu et al. 2014). Boakye et al. (2016b) reported that Geraniin is the major constituent of the plant with high therapeutic potentials (Boakye et al. 2016a). However, its potential against urinary tract infections has not been experimented or pharmacologically substantiated.

To support in vitro analysis, in silico investigations have been carried out to explain the mechanism of action of the 
potential antimicrobial compounds. Lee et al. (2016) and Gupta et al. (2013) stated that the in silico methods allow drug-ligand interaction studies to be performed in shorter periods and aids the designing of better therapeutic compounds (Lee et al. 2016; Gupta et al. 2013).

The docking program can be used to characterize the binding site, position the ligand into the binding site (orienting) and evaluate the strength of interaction for a specific ligand-receptor complex ("scoring"). Thus, docking program generates a pose after docking and energetically most favorable pose is identified by its scoring. Scoring is done for all molecules in the collection, which are then rank ordered by their scores. This rank-ordered list is then used to select those compounds that are predicted to be most active. Therefore, docking is useful for predicting the preferred orientation, strength and type of signal produced when two molecules bound to each other to form a stable complex, thus playing an important role in the rational design of drugs (Eweas et al. 2014).

A major factor that determines the suitability of a drug is how it interacts with the binding site of a therapeutically relevant biological macromolecule. Another important condition the drug must satisfy is the ability to get from the site of application to the target tissue, often passing through a complicated pathway consisting of aqueous phases and lipid membranes. At the target tissue, the drug elicit its biological activity, often referred to as pharmacodynamics (Klebe 2013). In contrast to pharmacodynamics, the sum of all processes that affect the absorption, distribution, metabolism and excretion (ADME parameters) of the drug is called pharmacokinetics. Pharmacokinetics is the effect of the organism on the drug, described using mathematical models. The term pharmacodynamics has expanded more and more to processes of pharmacokinetics due to emerging studies that show that transporters or enzyme systems are responsible for properties such as absorption, distribution or metabolism (Klebe 2013; Adeoye et al. 2020; Kitchen et al. 2004). This study is aimed at evaluating the antibacterial activity of the components of the leaf extract of $P$. muellerianus as well as their toxicity and drugability using in vitro and in silico approach.

\section{Materials and methods}

\section{Preparation of plant extract}

This was done using the method described by Oluwafemi and Debiri (2010) with slight modifications (Oluwafemi and Debiri 2010). The leaves of $P$. muellerianus were air-dried and chopped into small pieces. This was thereafter pulverized using a blender and the powdered mass was kept in an air-tight container for further use. Two hundred grammes
( $200 \mathrm{~g}$ ) of the pulverized leaves were macerated with $2 \mathrm{~L}$ of $60 \%$ methanol and stirred continuously for $72 \mathrm{~h}$ to ensure homogeneity. The mixture was then filtered using Whatman No. 1 filter paper and the filtrate evaporated to semi solid mass using a rotary evaporator and subsequently dried in a petri dish in the desiccator. The crude extracts were purified by solvent partitioning using various solvents in order of their polarity. The dried crude extract obtained was reconstituted with distilled water and poured into the separating funnel after which $\mathrm{N}$-hexane was added and swirled gently to mix. The mixture was left to settle into layers before collecting the $\mathrm{N}$ - hexane fraction. This process was repeated until there is no more change in the colour of the N-hexane. Dichloromethane (DCM) was thereafter added to the remaining solution and its fractions were also collected followed by Ethyl Acetate and lastly Butanol. The remaining solution of the extract was taken as the aqueous fraction. The various fractions of the extracts in solution were concentrated to dryness using the rotary evaporator while the aqueous fraction was lyophilized.

\section{Antimicrobial activity (Agar Well Diffusion Assay)}

The purified extracts of $P$. muellerianus were dissolved in sterile water at $50 \mathrm{mg} / \mathrm{ml}$ concentration. The test organisms used (Escherichia coli, Staphylococcus aureus, Klebsiella pneumoniae, Citrobacter sp., Proteus mirabilis, Enterobacter sp. Coagulase negative Staphylococcus aureus and Candida albicans) were standardized with sterile saline $(\mathrm{NaCl}$ $0.9 \%)$, and the turbidity was adjusted to the standard inoculums of a McFarland scale of $0.5\left(1.0 \times 10^{8}\right.$ colony forming units $/ \mathrm{ml}$ ). Briefly, agar plates containing $20 \mathrm{ml}$ of Mueller Hinton Agar (Oxoid Ltd., Hampshire UK) were inoculated with the bacterial and fungal strains under aseptic conditions and wells (diameter $=8 \mathrm{~mm}$ ) were filled with $100 \mu \mathrm{L}$ of the extracts. The experiment was repeated in triplicates and the mean zone of inhibition was recorded after incubating the test organisms at $37^{\circ} \mathrm{C}(24 \mathrm{~h})$.

\section{Determination of the minimum inhibitory concentration (MIC)}

The fraction that showed higher yield and antibacterial activities was subjected to MIC (minimum inhibitory concentration) assays (Akinpelu and Onakoya 2006). Serial dilutions were prepared with concentrations ranging from 0.195 to $100 \mathrm{mg} / \mathrm{ml}$. Sterile water was used as a negative control (Blank sterile water). Each prepared concentration (of $2 \mathrm{ml}$ ) in tubes was mixed with $18 \mathrm{ml}$ of sterile nutrient agar (Oxoid Ltd., Hampshire UK) plates that were inoculated with $100 \mu \mathrm{l}$ each of the $10^{8} \mathrm{cfu} / \mathrm{ml}$ bacterial and spore suspension from fungal strains. The plates were incubated aerobically at $37{ }^{\circ} \mathrm{C}(18-24 \mathrm{~h})$. The MIC values which represent the lowest 
compound concentration that completely inhibits the growth of microorganisms was recorded. All tests were performed in triplicates.

\section{Determination of minimum bactericidal concentration (MBC)}

Based on the MIC results obtained, the concentrations of all extracts that showed no growth were sub-cultured into sterile nutrient agar plates and incubated for $48 \mathrm{~h}$. The MBC was taken as the least concentration that did not show any growth on the agar plates.

\section{Antibiotic sensitivity test}

Kirby Bauer's disk diffusion method was employed to determine the effect of standard antibiotics against the test microorganism. Ten different standard antibiotics (Oxoid Ltd., Hampshire UK) were used for this study. They include Ciprofloxacin, Gentamicin, Ampicillin, Cefoxitin, Chloramphenicol, Nalidixic acid, Amoxycillin/Clavulanic acid, Sulphamethoxazol/Trimethoprim, Amikacin and Tetracycline. These antibiotic discs were placed aseptically on the plate already seeded with the test organisms using a pair of sterile forceps. The plates were thereafter incubated at $37{ }^{\circ} \mathrm{C}$ for $24 \mathrm{~h}$. After incubation, zone of growth inhibition was measured and recorded. This experiment was carried out in duplicates. The result obtained was thereafter interpreted using the Clinical and Standard Laboratory Institute (CLSI) chart (CLSI, 2013) and European Committee on Antimicrobial Susceptibility Testing (EUCAST) guidelines (Clinical and Standard Laboratory Institute (CLSI). 2013; European Committee on Antimicrobial Susceptibility Testing (EUCAST) 2018).

\section{Determination of the rate of kill}

The killing rate of the most active extract on the most susceptible bacterial isolate was carried out according to the method described by Odenholt et al. (2001) with little modifications. $0.5 \mathrm{ml}$ of the standardized bacterial suspension was first serially diluted using sterile saline to obtain ten dilution factors $\left(10^{-1}, 10^{-2}, 10^{-3}, 10^{-4}, 10^{-5}, 10^{-6}, 10^{-7}, 10^{-8}\right.$, $10^{-9}$ and $10^{-10}$ ) these dilutions were then seeded into nutrient agar plates using the pour plate technique. Heterogeneous plate count was then carried out to determine the viable microbial population count in each dilution factor to serve as reference for the rate of kill (Odenholt et al. 2001).

Thereafter, $2 \mathrm{ml}$ of the standardized bacterial suspension was added to $18 \mathrm{ml}$ of the most active fraction of the extract at a concentration equal to $1 \times \mathrm{MIC}$ and $2 \times \mathrm{MIC}$ values. This mixture was thoroughly shaken together and exactly $0.5 \mathrm{ml}$ of the mixture was immediately transferred into $4.5 \mathrm{ml}$ of
$3 \%$ Tween-80 nutrient broth and the suspension was thoroughly mixed. This serve as the portion taken at $0 \mathrm{~min}$ as this was done at $15 \mathrm{~min}$ interval for $2 \mathrm{~h}$. Exactly $0.5 \mathrm{ml}$ was taken from each suspension and serially diluted up to $10^{-6}$ in $4.5 \mathrm{ml}$ sterile normal saline. Then, $0.5 \mathrm{ml}$ of the final dilution factor was transferred into labeled pre-sterilized molten nutrient agar plates. This plate was incubated at $37^{\circ} \mathrm{C}$ for $24 \mathrm{~h}$. The time at which the least number of viable counts was obtained was recorded as the time it will take the antimicrobial agent to kill the organism.

\section{Determination of possible mechanism of action by Nucleotide Leakage}

The modified method as described by Miksusanti et al. (2008) was used to determine the leakage of nucleotides from the cells of the test organisms. Cells of Staphylococcus aureus and Candida albicans was standardized with saline and treated with various concentration of the extract relative to the MIC at various time intervals for $2 \mathrm{~h}$. Each suspension was then centrifuged at 10,000 rpm and the optical density of the supernatant collected was measured at $595 \mathrm{~nm}$ wavelength using a Spectrophotometer. Sterile saline inoculated with the same quantity of inoculums was used as control (Miksusanti et al. 2008).

\section{Determination of possible mechanism of action by Protein Leakage}

The leakage of proteins from the cells of the test organisms was also determined. Cells of Staphylococcus aureus and Candida albicans was standardized with saline and treated with various concentration of the extract relative to the MIC at various time intervals for $2 \mathrm{~h}$. Each suspension was then centrifuged at $10,000 \mathrm{rpm}$ and $0.2 \mathrm{ml}$ of the supernatant was taken and mixed with $1.4 \mathrm{ml}$ of distilled water. $0.4 \mathrm{ml} \mathrm{Brad-}$ ford's reagent was thereafter added to the mixture. Normal saline inoculated with the same quantity of inoculums was used as control. Optical Density (OD) of the resulting solution was thereafter taken at $595 \mathrm{~nm}$ after $5 \mathrm{~min}$. The Concentration of protein leaked was calculated using the Optical density extrapolated from the equation of the best linear regression line obtained from the graph of bovine serum albumin (BSA) standard curve (Miksusanti et al. 2008).

\section{Antioxidant analysis of $P$. muellerianus Leaf extract}

The various extracts were also tested for antioxidant properties. The properties assayed include Total antioxidant capacity (TAC), Total flavonoids, Total Phenol, Ferric Reducing Antioxidant Power (FRAP). 


\section{Metabolite profiling with GCMS Analysis}

Physicochemical analysis of the extract was performed using Shimadzu GC-MS-QP 2010 Ultra equipped with a SLB-5 ms Column fused with silica capillary $(0.20 \mathrm{~mm} \mathrm{X}$ $30.0 \mathrm{~m})$. The initial temperature was maintained at $40^{\circ} \mathrm{C}$ for $3 \mathrm{~min}$ and then heated at a rate of $15^{\circ} \mathrm{C}$ per minute up to $290{ }^{\circ} \mathrm{C}$ with a director voltage relative to the tuning result. Carrier gas Helium was used at a rate of $1 \mathrm{ml}$ per minute. n-Hexane was first used to flush the columns to reduce noise or false peaks. The extract was thereafter introduced into the GC-MS equipment. Different components present were identified with their various peaks and other chemical properties were afterwards obtained.

\section{Drug metabolism and pharmacokinetics}

\section{ADMET studies}

The ADMET (absorption, distribution, metabolism, elimination, and toxicity) studies of profiles compounds obtained from Shimadzu GC-MS-QP 2010 Ultra were carried out using pkCSM tool (http://biosig.unimelb.edu.au/pkcsm/prediction) and SwissADME (Daina et al. 2017; Pires et al. 2015). The profiled compounds were first screened for their physicochemical properties to determine the Pharmaceutical Active Ingredients (PAIs) using Lipinski rule of five (Molecular weight, logarithms of partial coefficient, hydrogen bond donor (HBD) and hydrogen bond acceptor (HBA)) (Lipinski et al. 1997). The canonical SMILES for the molecular structures of each of the compounds were obtained from PubChem (https://pub-chem.ncbi.nlm.nih.gov). The compounds with desirable physicochemical properties were further filtered for pharmacokinetic properties.

\section{Molecular docking}

\section{Ligand preparation}

The SDF structure of the ligands was retrieved from the PubChem database (www.pubchem.ncbi.nlm.nih.gov) (Kim et al. 2019). The compounds were converted to.pdb chemical format using PYMOL molecular graphics system (1.7.4.5 Edu) (DeLano 2002). Polar hydrogens were added while non-polar hydrogens were merged with the carbons and the internal degrees of freedom and torsions were set. The ligand molecules were further converted to the dockable. pdbqt format using Autodock vina program.

\section{Enzyme preparation}

The crystal structure of HMG-CoA (1TXT) was retrieved from the protein databank (www.rcsb.org) (Berman et al. 2000).
The crystal structure was prepared individually by removing existing ligands and water molecules, while missing hydrogen atoms were added using Autodock vina program, Scripps Research Institute. Thereafter, non-polar hydrogens were merged while polar hydrogen were added to the enzyme. The enzyme was subsequently saved into pdbqt. format in preparation for molecular docking.

\section{Scoring and analysis}

The molecular docking analysis was executed to ascertain the binding conformation of the protein-ligand complex using AutoDock vina (Trott and Olson 2010). The binding conformation would aid to reveal the binding energy of the HMG-CoA and Quindoline. The ligands side chain and the torsional bonds kept flexible while the HMG-CoA fixed rigid. All the ligands were docked to the residue involved in catalytic activity with $\mathrm{x}, \mathrm{y}$, and $\mathrm{z}$ coordinates of 7.000, -7.250 and 68.750 respectively. The grid box was set at $74 \AA \times 78 \AA \times 56 \AA$ and with an exhaustiveness of 8 . The free binding energy ( $\Delta \mathrm{G}$ bind) was calculated using the sum of van der Waals energy ( $\Delta \mathrm{G} \mathrm{vdw}$ ), the sum of electrostatic energy ( $\Delta \mathrm{G}$ elect), the sum of hydrogen bond and desolvation energy ( $\Delta \mathrm{G}$ hbond), the sum of final total internal energy ( $\Delta \mathrm{G}$ conform), the sum of torsional free energy ( $\Delta \mathrm{G}$ tor) and the sum unbound system energy ( $\Delta \mathrm{G}$ solv)(Isa et al. 2020). The compounds were then ranked by their binding affinity scores. Molecular interactions between the receptors and compounds with most remarkable binding affinities were first viewed with PYMOL after which further graphical analysis was obtained using Discovery Studio Visualizer, BIOVIA, 2016.

\section{Result}

\section{Antimicrobial studies}

\section{Antimicrobial activities of the purified fractions of $P$. muellerianus}

The four fractions tested showed considerable zones of inhibition on all the test organisms. 50\% of the organisms showed the highest susceptibility to Ethyl acetate and Dichloromethane (DCM) fractions while the aqueous fraction had the lowest zones of inhibition on all the organisms. Figure 1 shows the various zones of inhibition of all the organisms tested in this study.

\section{Minimum inhibitory and minimum bactericidal concentration}

The Minimum inhibitory concentration (MIC) of the ethyl acetate fraction was also determined and the result indicated 
Fig. 1 Antimicrobial activity of the fractions of P. muellerianus

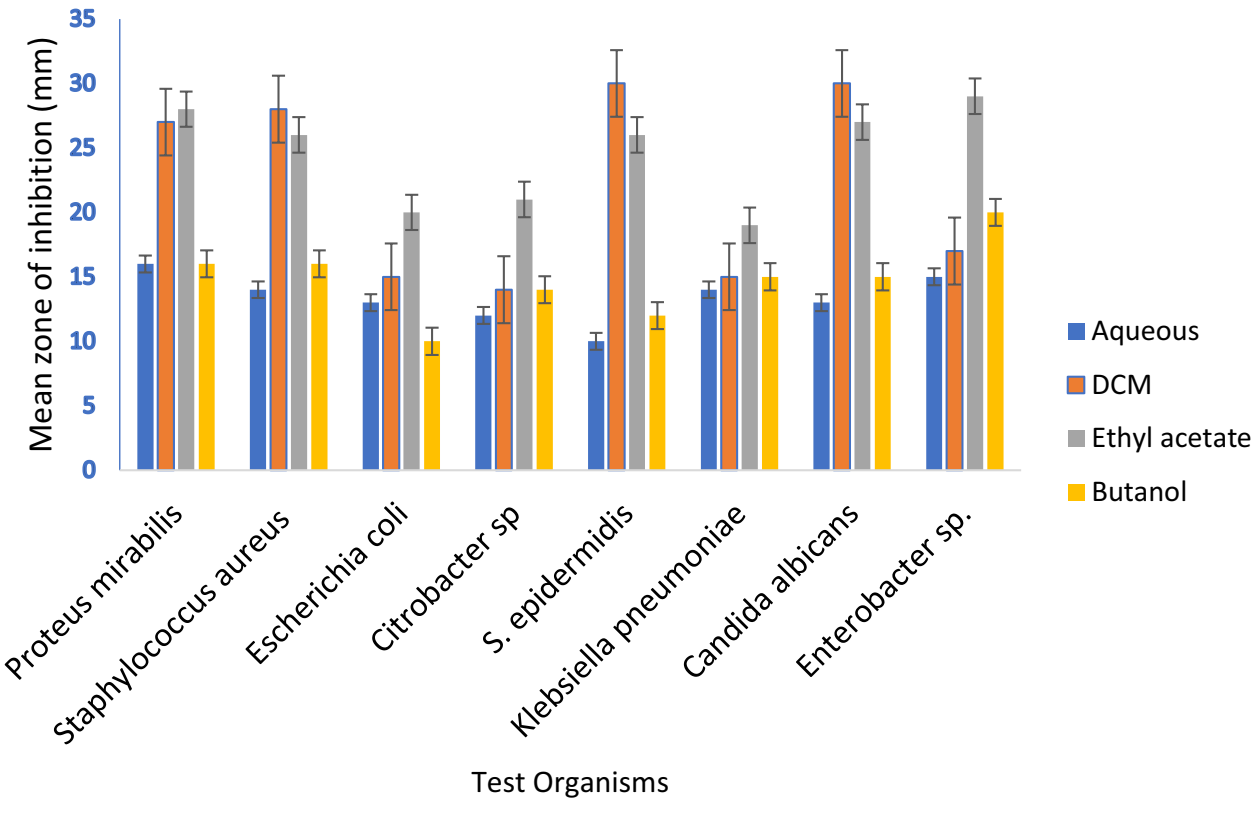

Table 1 MIC and MBC for Ethyl acetate fraction of P. muellerianus

\begin{tabular}{lll}
\hline Organisms & MIC $(\mathrm{mg} / \mathrm{ml})$ & MBC $(\mathrm{mg} / \mathrm{ml})$ \\
\hline Proteus mirabilis & 6.25 & 25 \\
Staphylococcus aureus & 12.5 & 25 \\
Escherichia coli & 12.5 & 25 \\
Citrobacter sp. & 12.5 & 25 \\
Staphylococcus epidermidis & 12.5 & 25 \\
Klebsiella pneumonia & 25 & 50 \\
Candida albicans & 6.25 & 25 \\
Enterobacter sp. & 6.25 & 25 \\
\hline
\end{tabular}

that $37.5 \%$ had a MIC of $6.25 \mathrm{mg} / \mathrm{ml}$ while others except Klebsiella pneumoniae had a concentration of $12.5 \mathrm{mg} /$ $\mathrm{ml}$. Further analysis into the MBC revealed all test organisms except Klebsiella pneumoniae had MBC of $25 \mathrm{mg} / \mathrm{ml}$. Table 1 shows the MIC and MBC value for all the organisms by Ethyl acetate fraction of $P$. muellerianus.

\section{Antibiotic sensitivity of all test organisms}

The result of the antibiotics sensitivity test as shown in Tables 2 and 3 indicates that Proteus mirabilis was resistant to 7 of the antibiotics used, Citrobacter $s p$. was resistant to 5 antibiotics, Staphylococcus aureus, Enterobacter sp. and Candida albicans were resistant to 4 of the antibiotics while Klebsiella pneumoniae and Escherichia coli was resistant to only 3 antibiotics.

However, $75 \%$ of the organisms tested were resistant to the penicillin and cephalosporin group of antibiotics, $62.5 \%$ were resistant to Chloramphenicol and Sulphamethoxazole/ Trimetoprim. In addition, the Aminoglycosides were shown to possess great antimicrobial activity against all isolates tested. Also, with the exception of Proteus mirabilis, all organisms were sensitive to the Fluoroquinolones.

\section{Rate of kill of the ethyl acetate fraction of $P$. muellerianus}

The time rate of kill of the extract as depicted in Figs. 2 and 3 indicates a continuous decrease in the cell population as the time of exposure increases. For Staphylococcus aureus, at $\mathrm{MIC} \times 1$, the colony forming unit ( $\mathrm{cfu}$ ) counted at $0 \mathrm{~min}$ was $62 \times 10^{6} \mathrm{cfu} / \mathrm{ml}$ which progressively decreases to $1 \times 10^{3} \mathrm{cfu} / \mathrm{ml}$ at $120 \mathrm{~min}$. Similarly at MIC $\times 2,51 \times 10$ ${ }^{6} \mathrm{cfu} / \mathrm{ml}$ was recorded at $0 \mathrm{~min}$ while at $120 \mathrm{~min}, 3 \times 10^{2} \mathrm{cfu} /$ $\mathrm{ml}$ was observed.

Furthermore, Candida albicans experienced continuous decrease in cell population as the exposure time increases. At MIC $\times 1$, the cell population was $39 \times 10^{7} \mathrm{cfu} / \mathrm{ml}$ at $0 \mathrm{~min}$ whereas at $120 \mathrm{~min}, 1 \times 10^{2} \mathrm{cfu} / \mathrm{ml}$ was observed. MIC $\times 2$ on the other hand, had a sharp decrease in cell population from $31 \times 10^{6} \mathrm{cfu} / \mathrm{ml}$ at $0 \mathrm{~min}$ to $1 \times 10^{1} \mathrm{cfu} / \mathrm{ml}$ at $120 \mathrm{~min}$. However, both controls did not exhibit significant decrease or increase in cell population.

\section{Mechanism of action of the ethyl acetate fraction of $P$. muellerianus}

The mechanism of action of the extract through nucleotide leakage indicates that as the exposure time increases, the rate of leakage also increases. Figure 4 shows the steady increase in the absorbance value of Staphylococcus aureus at MIC $\times 1$ and MIC $\times 2$ as time increases whereas, the control did not exhibit any significant change in the absorbance value. This 

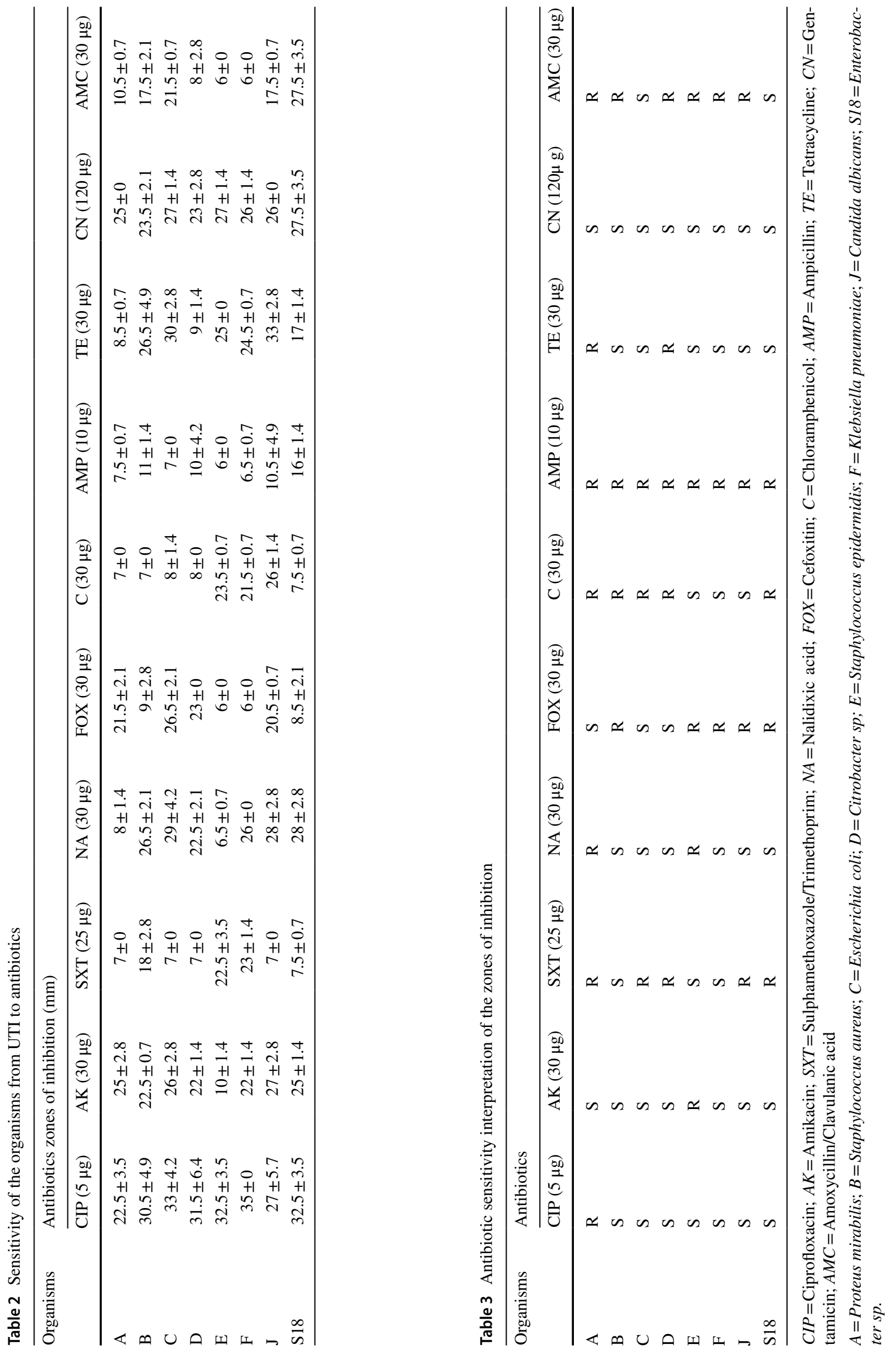


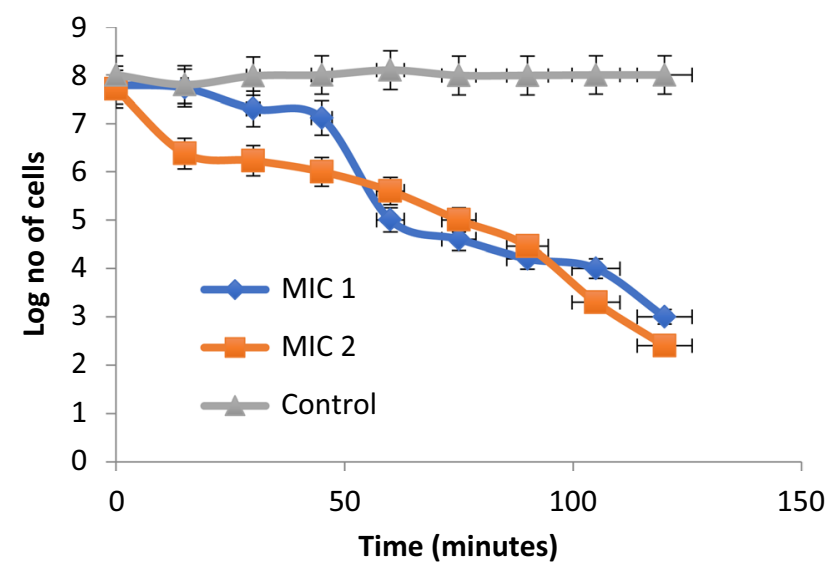

Fig. 2 Time rate of kill of the ethyl acetate fraction of P. muellerianus against Staphylococcus aureus

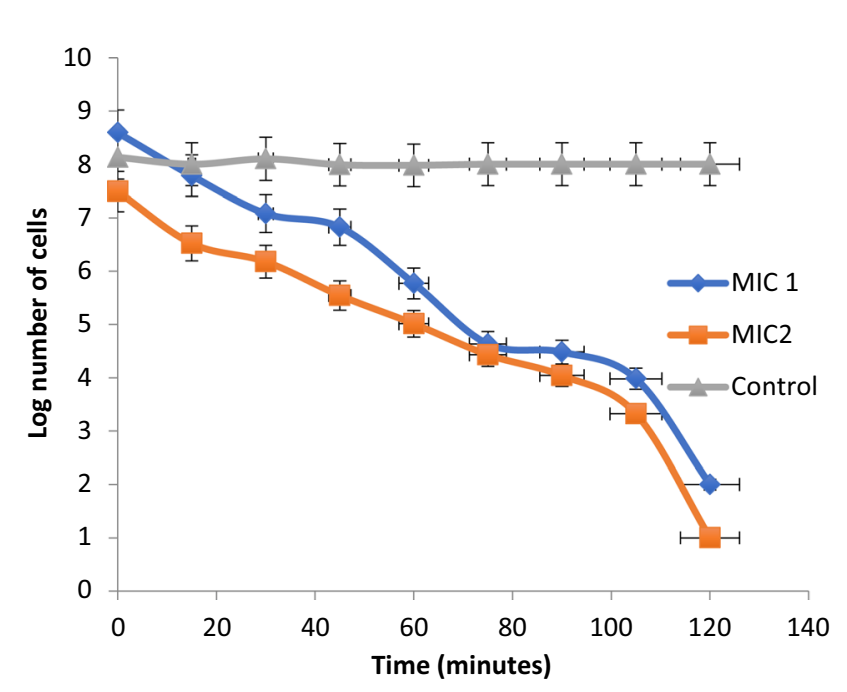

Fig. 3 Time rate of kill for Candida albicans by ethyl acetate fraction of P. muellerianus

is also same in Fig. 5 which shows the nucleotide leakage of Candida albicans at both MIC 1 and MIC 2.

In addition, the rate of protein leakage per time interval of Staphylococcus aureus was determined and the result in Fig. 6 shows a steady increase in protein concentration as exposure time increases. At $0 \mathrm{~min}, 9.29 \mu \mathrm{g} / \mathrm{ml}$ was observed, and this increased up to $11.86 \mu \mathrm{g} / \mathrm{ml}$ at $120 \mathrm{~min}$ for $\mathrm{MIC} \times 1$ while MIC $\times 2$ had a steady increase from $10.14 \mu \mathrm{g} / \mathrm{ml}$ at $0 \mathrm{~min}$ to $17.43 \mu \mathrm{g} / \mathrm{ml}$ at $120 \mathrm{~min}$. Candida albicans in Fig. 7 also exhibited this continuous increase in protein leakage at $\mathrm{MIC} \times 1$ and $\mathrm{MIC} \times 2$. At $0 \mathrm{~min}, 8.57 \mu \mathrm{g} / \mathrm{ml}$ was observed for MIC $\times 1$ while $\mathrm{MIC} \times 2 \mathrm{had} 23.14 \mu \mathrm{g} / \mathrm{ml}$ whereas at $120 \mathrm{~min}$ $52.57 \mu \mathrm{g} / \mathrm{ml}$ and $70.43 \mu \mathrm{g} / \mathrm{ml}$ was recorded for MIC $\times 1$ and $\mathrm{MIC} \times 2$ respectively. The control for both organisms did not show significant change in concentration.



Fig. 4 Rate of Nucleotide leakage of Staphylococcus aureus

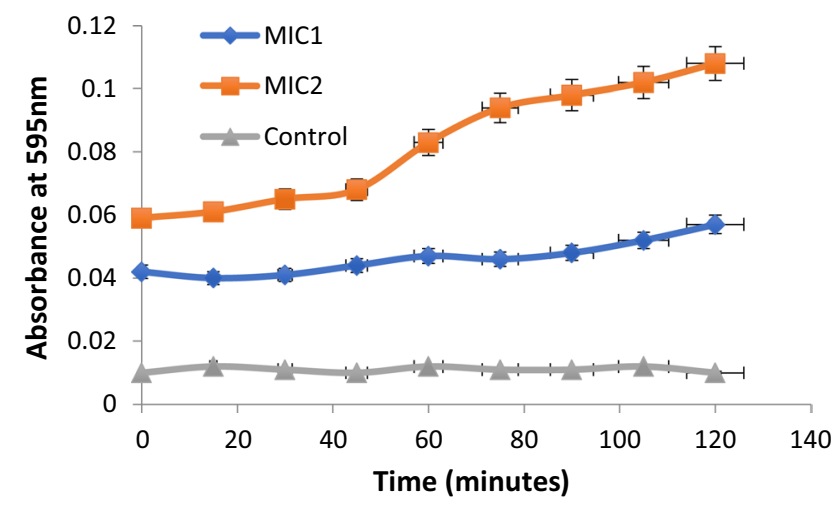

Fig. 5 Nucleotide leakage for Candida albicans by ethyl acetate fraction of $P$. muellerianus

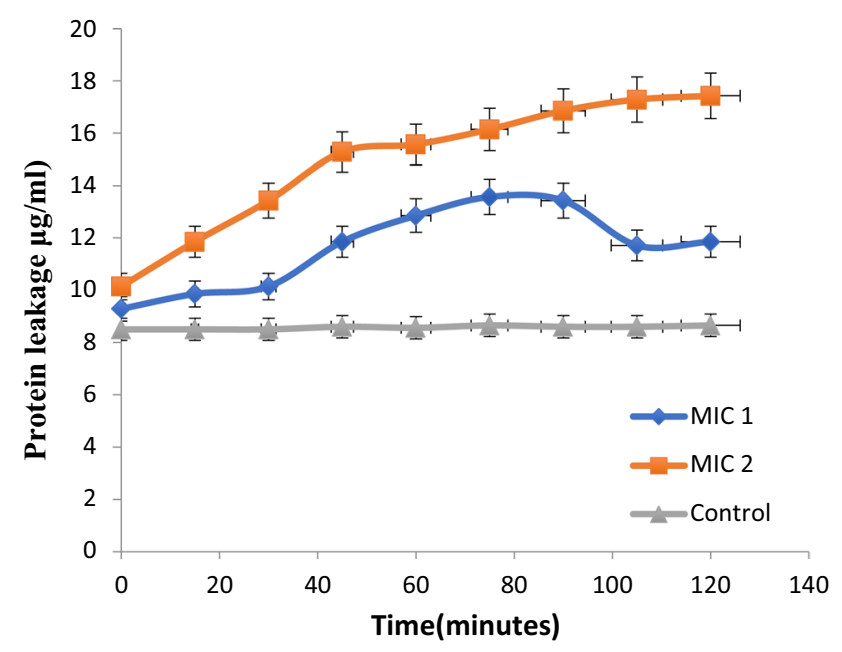

Fig. 6 Protein leakage for Staphylococcus aureus 


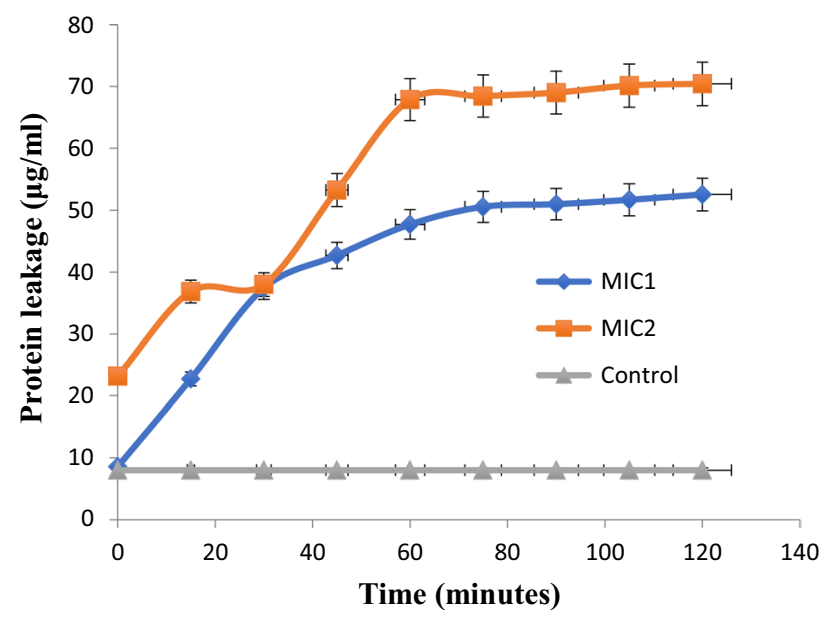

Fig. 7 Protein leakage for Candida albicans

Table 4 Antioxidant assays on P. muellerianus

\begin{tabular}{llr}
\hline S/N & ANTIOXIDANT ASSAYS & P. muellerianus \\
\hline 1 & TAC $(\mathrm{mg} / \mathrm{g})$ & 9.15 \\
2 & Total Flavonoids (mgQUE/g) & 190.36 \\
3 & FRAP(mgAAE/g) & 6.36 \\
4 & Total Phenol (mgGAE/g) & 23.56 \\
\hline
\end{tabular}

\section{Antioxidant analysis of $P$. muellerianus}

Table 4 shows the antioxidant activity of and P. muellerianus using the parameters of Total Antioxidant Capacity (TAC), Total flavonoids, Ferric Reducing Antioxidant Power (FRAP) and Total Phenol.

\section{ADME pharmacokinetics studies}

The GC-MS analysis of the components (ligands) of $P$. muellerianus showed the presence of 8,11,14-eicosatrienoic acid, 9,12,15-octadecatrienoic acid, 2-Methoxyl-4vinylglycine, Bis (2-ethylhexyl)phthalate, 2-methoxy-4vinyl phenol, 2- (1- Adamantyl)-N-benzylglycine, alpha-D-Galactopyranoside, Quindoline, Benzofuran, 1,2,3,-Benzetriol, and Phytol. In addition, the results of the pharmacokinetics and pharmacodynamics properties of profiled ligands from P. muellerianus are presented in Tables 5, $6,7,8,9$, and 10. All the ligands passed the Lipinski rule of five except for 8,11,14-eicosatrienoic acid, 9,12,15-octadecatrienoic acid, bis (2-ethylhexyl) phthalate and phytol which has $\log \mathrm{P}$ values above 5 as seen in Table 5 .

The distribution of a substance in phases of different lipophilicities is measured as the partition coefficient $\mathrm{P}(\log$ $\mathrm{P})$. Lipophilicity plays a vital role in the assessment of the therapeutic suitability of a drug. It is a substitute to in vivo studies which are important complements in drug discovery. With the exception of substances that are taken up via a transporter, the absorption is usually better when the compounds are more lipophilic as in the case of quindoline and (1-adamantyl) benzylglycine with $\log \mathrm{P}$ values of 3.8693 and 3.4458 respectively. This advantage is limited by the solubility in aqueous phases, which decreases severely as the lipophilicity increases. As seen in Table 6, water solubility ( $\log \mathrm{mol} / \mathrm{L}$ ) decreases proportionately for all the ligands. However, a negative $\log \mathrm{P}$ value for b-D-glucopyranose means the ligand is a hydrophilic drug whose intake could negatively impact permeability.

The excretion path also depends on the lipophilicity of the ligand. Our study shows that extremely lipophilic substances are more quickly metabolized (as seen in Table 7), but are also toxicologically worrisome (Table 8). Only quindoline and 2-methoxyl-4-vinylglycine are substrates of renal organic cation transporter while other drugs are possibly
Table 5 Lipinski's rule of five

\begin{tabular}{llcll}
\hline Model Name & Molecular weight & Log P $(\leq 5)$ & $\begin{array}{l}\mathrm{H} \text { - bond accep- } \begin{array}{l}\mathrm{H}-\text { bond } \\
\text { tors }(\leq 10)\end{array} \\
\text { donors }(\leq 5)\end{array}$ \\
\hline Quindoline & 218.253 & 3.8693 & 1 & 1 \\
Benzofuran & 118.135 & 2.4328 & 1 & 0 \\
1,2,3-benzetriol & 126.111 & 0.8034 & 3 & 3 \\
(1-Adamantyl)benzylglycine & 299.414 & 3.4458 & 2 & 2 \\
2-Methoxyl-4-vinylglycine & 150.177 & 2.0438 & 2 & 1 \\
8,11,14-eicosatrienoic acid & 306.49 & 6.4407 & 1 & 1 \\
9,12,15-octadecatrienoic acid & 278.436 & 5.6605 & 1 & 1 \\
B-D-glucopyranose & 180.156 & -3.2214 & 6 & 5 \\
Bis (2-ethylhexyl)phthalate & 390.564 & 6.433 & 4 & 0 \\
Phytol & 296.539 & 6.3641 & 1 & 1 \\
Ciprofloxacin & 331.347 & 1.5833 & 5 & 2 \\
\hline
\end{tabular}


Table 6 Molecular and absorption prediction of profiled lead compounds

\begin{tabular}{|c|c|c|c|c|c|c|c|c|}
\hline Model name & $\begin{array}{l}\text { Lipophilic- } \\
\text { ity }(\log \text { P) }\end{array}$ & $\begin{array}{l}\text { Water } \\
\text { solubility (Log } \\
\mathrm{mol} / \mathrm{L})\end{array}$ & $\begin{array}{l}\text { Caco2 permeabil- } \\
\text { ity (Log Papp in } \\
10-6 \mathrm{~cm} / \mathrm{s})\end{array}$ & $\begin{array}{l}\text { Human intesti- } \\
\text { nal absorption } \\
(\%)\end{array}$ & $\begin{array}{l}\text { Skin perme- } \\
\text { ability (Log } \\
\text { Kp) }\end{array}$ & $\begin{array}{l}\mathrm{P}-\text { glyco- } \\
\text { protein } \\
\text { substrate }\end{array}$ & $\begin{array}{l}\mathrm{P}-\text { glyco- } \\
\text { protein I } \\
\text { inhibitor }\end{array}$ & $\begin{array}{l}\mathrm{P} \text {-glyco- } \\
\text { protein II } \\
\text { inhibitor }\end{array}$ \\
\hline Quindoline & 3.8693 & -4.272 & 1.215 & 94.036 & -2.746 & Yes & No & No \\
\hline Benzofuran & 2.4328 & -2.015 & 1.581 & 95.557 & -1.506 & No & No & No \\
\hline $1,2,3$-benzetriol & 0.8034 & -1.408 & 1.122 & 83.549 & -2.751 & No & No & No \\
\hline $\begin{array}{c}\text { (1-Adamantyl) } \\
\text { benzylglycine }\end{array}$ & 3.4458 & -2.891 & 1.341 & 94.231 & -2.735 & No & No & No \\
\hline $\begin{array}{l}\text { 2-Methoxyl-4- } \\
\text { vinylglycine }\end{array}$ & 2.0438 & -1.958 & 1.499 & 91.965 & -2.262 & No & No & No \\
\hline $\begin{array}{l}8,11,14-\text { eicosa- } \\
\text { trienoic acid }\end{array}$ & 6.4407 & -6.095 & 1.575 & 92.148 & -2.729 & No & No & No \\
\hline $\begin{array}{l}9,12,15 \text { - octade- } \\
\text { catrienoic acid }\end{array}$ & 5.6605 & -5.787 & 1.577 & 92.836 & -2.722 & No & No & No \\
\hline $\begin{array}{l}\mathrm{B}-\mathrm{D}-\mathrm{glu}- \\
\text { copyranose }\end{array}$ & -3.2214 & -1.377 & -0.249 & 21.51 & -3.041 & No & No & No \\
\hline $\begin{array}{l}\text { Bis (2-ethyl- } \\
\text { hexyl)phthalate }\end{array}$ & 6.433 & -6.47 & 1.408 & 92.45 & -2.67 & No & Yes & Yes \\
\hline Phytol & 6.3641 & -7.554 & 1.515 & 90.71 & -2.576 & No & No & Yes \\
\hline Ciprofloxacin & 1.5833 & -2.897 & 0.492 & 96.466 & -2.734 & Yes & No & No \\
\hline
\end{tabular}

Table 7 Predicted in vivo clearance/excretion of profiled lead compounds

\begin{tabular}{lll}
\hline Model name & $\begin{array}{l}\text { Total clearance } \\
(\text { logml/min/kg })\end{array}$ & $\begin{array}{l}\text { Renal OCT } \\
\text { 2 substrate }\end{array}$ \\
\hline Quindoline & 0.823 & Yes \\
Benzofuran & 0.353 & No \\
1,2,3-benzetriol & 0.104 & No \\
(1-Adamantyl)benzylglycine & 0.537 & No \\
2-Methoxyl-4-vinylglycine & 0.223 & Yes \\
8,11,14-eicosatrienoic acid & 2.052 & No \\
9,12,15-octadecatrienoic acid & 1.991 & No \\
B-D-glucopyranose & 0.626 & No \\
Bis (2-ethylhexyl)phthalate & 1.898 & No \\
Phytol & 1.686 & No \\
Ciprofloxacin & 0.633 & No \\
\hline
\end{tabular}

cleared through other available routes such as bile, breath, faces and sweat.

Also, the study revealed that Bis (2-ethylhexyl) phthalate and phytol exerted an inhibitory effect on hERG II but none of the ligands interacted with hERG I. Adeoye et al. (2020) has earlier reported that administration of lopinavir, remdesivir, and chloroquine could result in delayed ventricular repolarisation through inhibition of the hERG potassium channel leading to normal cardiac function compromise and disruption of hepatic functions(Adeoye et al. 2020). However, none of this compound was observed to trigger hepatotoxicity. Instead, only (1-adamantyl) benzylglycine, 9,12,15-octadecatrienoic acid and ciprofloxacin (standard drug) were observed to induce hepatotoxicity but no inhibitory effect on hERG I or II (Table 8).

Predictive appraisal of the drugs' distribution through the nervous system showed that lipophilicity of the drugs correlates significantly with the tendency to permeate the blood-brain barrier $(\log \mathrm{BB})$ and the central nervous system (log PS). Quindoline, benzofuran, (1-adamantyl) benzylglycine, 2-methoxyl-4-vinylglycine and phytol showed favourable penetration through the blood-brain barrier while all the ligands were quite unfavourable towards CNS- penetration (Table 10). Klebe 2013 reported that the optimum lipophilicity required for a drug to cross the blood-brain barrier is in the range of $\log P=1.5-2.5$ while for CNSactive substances, an optimal lipophilicity around $\log P=2$ should be aimed for in order to facilitate penetration across the blood-brain barrier. Also, the predicted steady-state volume of distribution (VDss) showed that (1-adamantyl) benzylglycine, 8,11,14-eicosatrienoic acid, 9,12,15-octadecatrienoic acid and ciprofloxacin had lower theoretical dose required for uniform distribution in the plasma.

\section{Molecular docking studies}

The in silico study predicted the molecular interaction between profiled ligands from P. muellerianus and 3hydroxyl-3-methylglutaryl CoA (HMG-CoA) reductase, (a mevalonate synthetase which is the enzyme responsible for the synthesis of peptidoglycan in Staphylococcus aureus and as such its inhibition leads to its inactivity), and showed that all the ligands exhibited relatively good interaction with the enzyme as predicted by their docking scores (Fig. 8). 


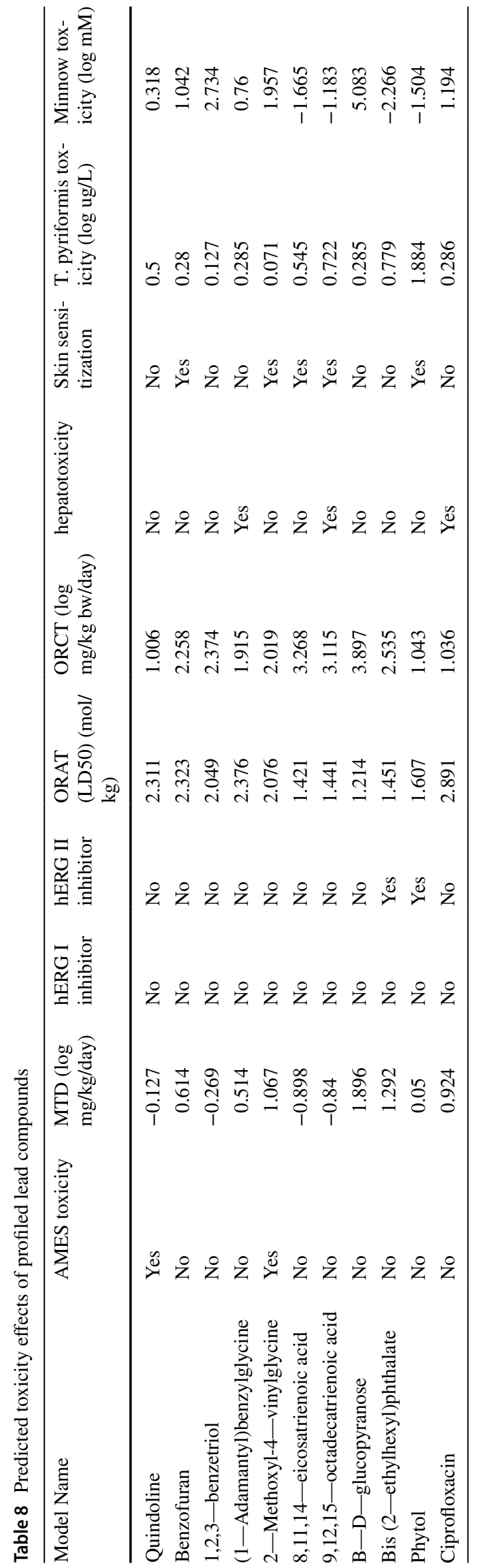

However, quindoline was selected for further molecular investigation after considering its pharmacodynamics and pharmacokinetic predictions, in addition to its docking score of $-9.1 \mathrm{kcal} / \mathrm{mol}$. This indicated a higher binding affinity to the pocket site of HMG-CoA when compared to ciprofloxacin, a common antibiotic used in the treatment of grampositive microorganisms has $-7.7 \mathrm{kcal} / \mathrm{mol}$ and Acetoacetyl CoA which is the natural substrate it binds with. Figure 9 shows the interaction of quindoline and the residues at the site of HMG-CoA and their corresponding orientations while Fig. 10 depicts Ciprofloxacin (CIP) binding orientation with residues of at site of HMG-CoA and their corresponding orientations.

Superimposition of Quindoline on ciprofloxacin (Fig. 11c) reveals interesting comparison between the two ligands, predicting our ligand as a drug-lead agent against HMG-CoA inhibition. Analyzing the structural and atomic orientations of quindoline $(15 \mathrm{C}, 2 \mathrm{~N}, 10 \mathrm{H})$, we observed the presence of azaindole backbone (4-azaindole moiety ring). Azaindoles are heterocyclic aromatic organic compounds, consisting of a pyrole ring fused to a pyridine ring (Zhao and Wang 2010). As isoteres of indoles, they exhibit excellent potential for biological activity. This structural conformation may have increased the stability of the ligand, effecting a stronger binding affinity of Quindoline-HMG-CoA complex. As earlier proposed by Taylor et al. (2002), binding affinity is a function of the stability of the ligand-target complex, conversely optimizing new bonds and increasing the biological activity of a complex molecule (Taylor et al. 2002).

\section{Discussion and conclusion}

This study has been able to show that $P$. muellerianus leaves extract exhibited high potency against the organisms used in this study which conforms with the reports of Doughari and Sunday (2008) who also reported the potency of $P$. muellerianus leaf extract (Doughari and Sunday 2008). Furthermore, Assob et al. (2011) have shown that the methanol and ethyl acetate stem bark and aqueous leaf extract of the plant possess antibacterial activity and this support the findings of our study (Assob et al. 2011). With further purification of the crude extract of $P$. muellerianus, Dichloromethane (DCM) and Ethyl acetate fraction had the highest zones of inhibition. This could be because DCM and ethyl acetate are able to leach out more flavonoids from the crude extract and these flavonoids account for the high antimicrobial activity (Cushnie and Lamb 2005). The rate of kill of the ethyl acetate fraction of $P$. muellerianus extract as depicted in this study indicates a continuous decrease in the cell population as the time of exposure increases for both concentrations of the MIC used. This is in line with the reports of Boakye et al. (2016b) who reported a gradual decrease in cell population 
Table 9 Predicted effect of profiled lead compounds on human Cytochrome P450

\begin{tabular}{|c|c|c|c|c|c|c|c|}
\hline Model Name & $\begin{array}{l}\text { CYP2D6 } \\
\text { substrate }\end{array}$ & $\begin{array}{l}\text { CYP3A4 } \\
\text { substrate }\end{array}$ & $\begin{array}{l}\text { CYP1A2 } \\
\text { inhibitor }\end{array}$ & $\begin{array}{l}\text { CYP2C19 } \\
\text { inhibitor }\end{array}$ & $\begin{array}{l}\text { CYP2C9 } \\
\text { inhibitor }\end{array}$ & $\begin{array}{l}\text { CYP2D6 } \\
\text { inhibitor }\end{array}$ & CYP3A4 \\
\hline Quindoline & No & Yes & Yes & Yes & Yes & Yes & Yes \\
\hline Benzofuran & No & No & Yes & No & No & No & No \\
\hline $1,2,3$-benzetriol & No & No & No & No & No & No & No \\
\hline (1-Adamantyl)benzylglycine & No & Yes & No & No & No & No & No \\
\hline 2-Methoxyl-4—vinylglycine & No & No & Yes & No & No & No & No \\
\hline $8,11,14$ - eicosatrienoic acid & No & Yes & Yes & No & No & No & No \\
\hline $9,12,15$ - octadecatrienoic acid & No & Yes & Yes & No & No & No & Yes \\
\hline B-D—glucopyranose & No & No & No & No & No & No & No \\
\hline Bis (2-ethylhexyl)phthalate & No & Yes & No & Yes & No & No & No \\
\hline Phytol & No & Yes & Yes & No & No & No & No \\
\hline Ciprofloxacin & No & No & No & No & No & No & No \\
\hline
\end{tabular}

Table 10 In vivo distribution prediction of profiled lead compounds

\begin{tabular}{lcccc}
\hline Model name & $\begin{array}{l}\text { Steady-state Volume of distri- } \\
\text { bution (VDss) }\end{array}$ & Fraction unbound & $\begin{array}{l}\text { Blood-brain barrier } \\
(\operatorname{logBB})\end{array}$ & $\begin{array}{l}\text { CNS perme- } \\
\text { ability (log } \\
\text { PS) }\end{array}$ \\
\hline Quindoline & 0.329 & 0.144 & 0.52 & -1.63 \\
Benzofuran & 0.081 & 0.357 & 0.276 & -1.797 \\
1,2,3-benzetriol & 0.13 & 0.712 & -0.441 & -3.252 \\
(1- Adamantyl)benzylglycine & -0.294 & 0.415 & 0.181 & -2.324 \\
2- Methoxyl-4-vinylglycine & 0.118 & 0.322 & 0.289 & -2.043 \\
$8,11,14$-icosatrienoic acid & -0.616 & 0.02 & -0.199 & -1.438 \\
$9,12,15$-octadecatrienoic acid & -0.617 & 0.056 & -0.115 & -1.547 \\
B-D-glucopyranose & 0.148 & 0.82 & -0.943 & -3.636 \\
Bis (2-ethylhexyl)phthalate & 0.36 & 0 & -0.175 & -2.213 \\
Phytol & 0.468 & 0 & 0.806 & -1.563 \\
Ciprofloxacin & -0.17 & 0.648 & -0.587 & -2.999 \\
\hline
\end{tabular}

for the first three hours(Boakye et al. 2016a). However, the rate of cell population decrease was faster in $\mathrm{MIC} \times 2$ than in $\mathrm{MIC} \times 1$, this result conforms to the popular assertion that says the higher the concentration, the higher the antimicrobial effect of the agent against organisms (Rutala and Weber 2013).

The mechanism of action of the ethyl acetate fraction of $P$. muellerianus in this study revealed that there was an increase in nucleotide and protein leakage as the exposure time increases. Stojkovic et al. (2013) posited that this is an indication that nucleotide materials (such as purine and pyrimidine bases) had been lost through a damaged cytoplasmic membrane since membrane integrity can be determined through the detection of absorbance at $260 \mathrm{~nm}$ because nucleotides have strong ultraviolet absorption at that wavelength (Stojkovic et al. 2013). The protein leakages on Staphylococcus aureus and Candida albicans could be due to an induced cell lysis by the components of $P$. muellerianus thus damaging the cell wall and membrane (Alwash et al. 2013).

The high antioxidant activities of $P$. muellerianus obtained in this study is in line with the findings of Boakye et al (2016c) who reported high FRAP values similar to this study. Higher FRAP values give higher antioxidant capacity because FRAP value is based on reducing ferric ion, where antioxidants are the reducing agents (Boakye et al. 2016b). The reducing power might be due to hydrogen donating ability, and is generally associated with the presence of reductones (Guo et al. 2003). High antioxidant activity of the plant extracts may be due to the high tannin content since the antioxidant activity of tannins is mediated through reducing power and scavenging activity (Shon et al. 2003; Minussi et al. 2003). Khan et al (2012) also reported that many flavonoids and related polyphenols contribute significantly to the antioxidant activity of medicinal plants (Khan et al. 2012). 
Fig. 8 Binding energy profile of $\mathrm{HMG}-\mathrm{CoA}$ Interaction with Ligands from $P$. muellerianus

Fig. 9 Quindoline (QUIN) interacting with the residues at the site of HMG-CoA and their corresponding orientations (a, b), binding attributes of bonds (c) and bond distance d (figure d); A:SER201:OG-N:QUIN (hydrogen bond, $d=3.09$ $\mathrm{A}^{0}$ ), A:PHE236-:QUIN (pi-pi T-shaped hydrophobic bond, $\mathrm{d}=4.99 \mathrm{~A}^{0}$ ), QUIN-:PRO235:A (pi-aliky hydrophobic bond, $\mathrm{d}=5.43 \mathrm{~A}^{0}, 4.57 \mathrm{~A}^{0}, 4.29$ $\left.\mathrm{A}^{0}\right), \mathrm{A}: \mathrm{CYS} 111: \mathrm{SG}-\mathrm{QUIN}$ (pi-sulphur bond, $\mathrm{d}=5.81$ $\mathrm{A}^{0}$ ), A:SCY111:SG-:QUIN (pi-sulphur bond, $\mathrm{d}=5.21$ $\mathrm{A}^{0}$ ), QUIN:H-OH:TYR143:A (hydrogen bond, $\mathrm{d}=2.23 \mathrm{~A}^{0}$ )
0

$-2$

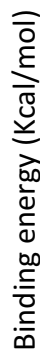
$-4$

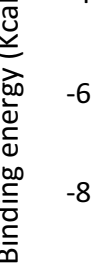

$-10$ $-12$
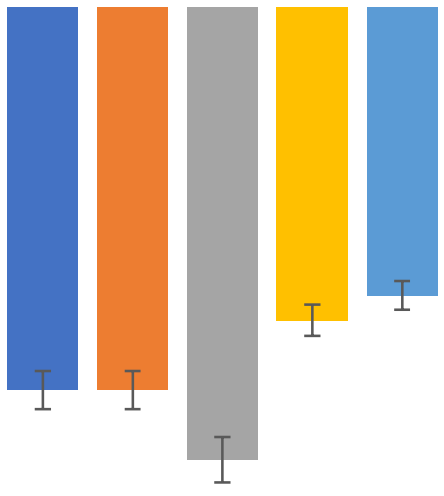

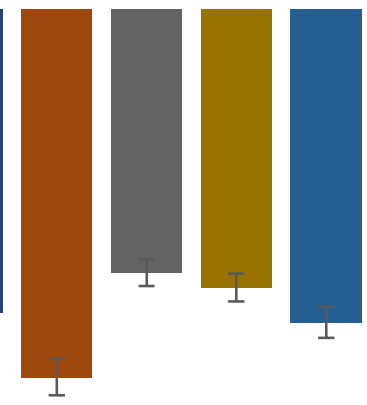
acetoacetylcoa
ciprofloxacin
quindoline
benzofuran
benzenetriol
phytol
glucoyrazole
घ adamantyl
- eicosatrienoic
n octadecatrienoic $\square$ methoxyl

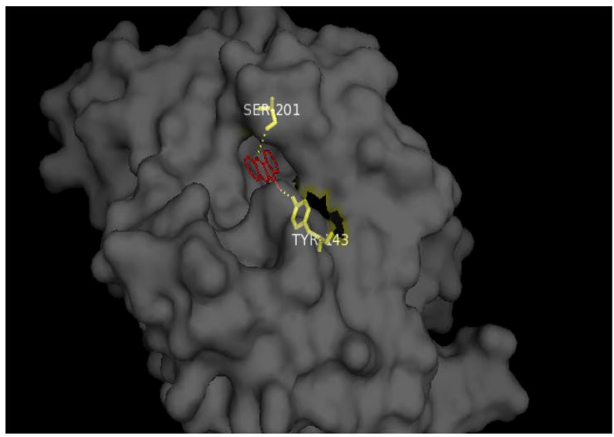

(a)

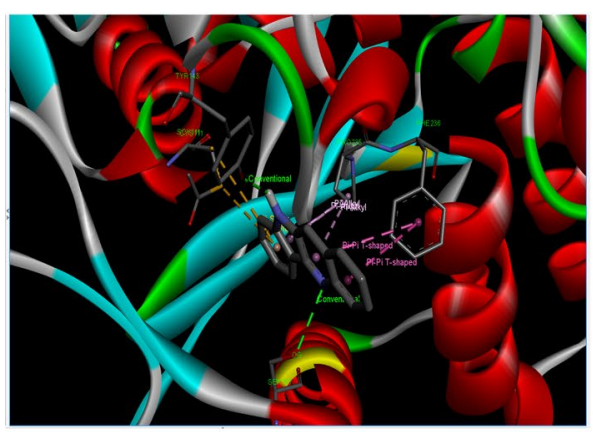

(c)

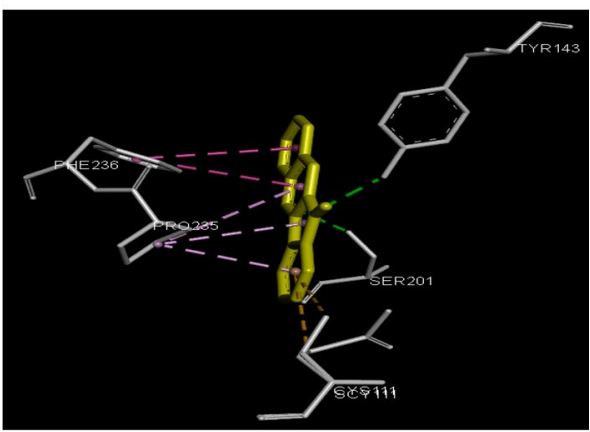

(b)

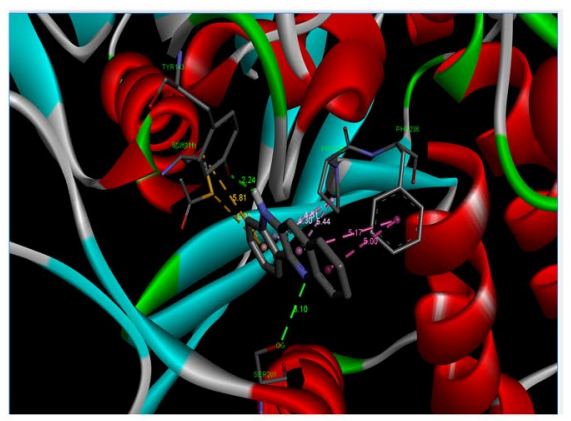

(d)
It must be noted that the reagent used for total phenolic content in the study does not react exclusively with phenolics, but also with other reducing agents; for example, ascorbic acid (Meda et al. 2005; Yang et al. 2006). Hence, results of this test therefore reflect the total antioxidant activity of the plant extracts used in this study.

The physicochemical analysis of $P$. muellerianus revealed the presence of several components which is in consonance with the reports of Boakye et al (2016a)(Boakye et al. 2016c). Saleem (2009) also isolated bis (2-ethyloctyl) phthalate, bis (2-ethylicosyl) phthalate, 3-friedelanone, methylgallate, $\alpha$-sitosterol which were also components isolated in this study (Saleem et al. 2009). It is however pertinent to point out that there were slight differences in the percentage abundance of the components obtained in this study as compared with the findings of Saleem (2009) and Boakye 
Fig. 10 Ciprofloxacin (CIP) binding orientation with residues of at site of HMG$\mathrm{CoA}$ and their corresponding orientations (a, b), binding attributes of bonds (c) and bond distance d (d); CIP:HA:GLU79:O (hydrogen bond, $\mathrm{d}=2.50 \mathrm{~A}^{0}$ ), CIP:-A:ARG187 (pi-alkyl hydrophobic bond, $\mathrm{d}=5.15 \mathrm{~A}^{0}$ ), A:ARG187:N:CIP (pi-donor hydrogen bond, $\mathrm{d}=3.88 \mathrm{~A}^{0}$ ), A:PHE185:O$\mathrm{F}: \mathrm{CIP}$ (halogen bond, $\mathrm{d}=2.76$ $\mathrm{A}^{0}$ ), A:SER307:O-F:CIP (halogen bond, $d=2.97 \mathrm{~A}^{0}$ ), CIP:C-OE1:GLU109:A (hydrogen bond, $d=3.58 \mathrm{~A}^{0}$ ), CIP:ALA110:A (pi-alkyl hydrophobic bond, $d=5.38 \mathrm{~A}^{0}$ )



(a)

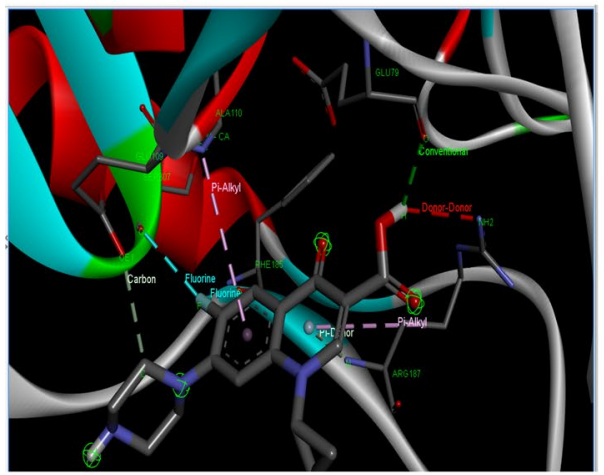

(c)

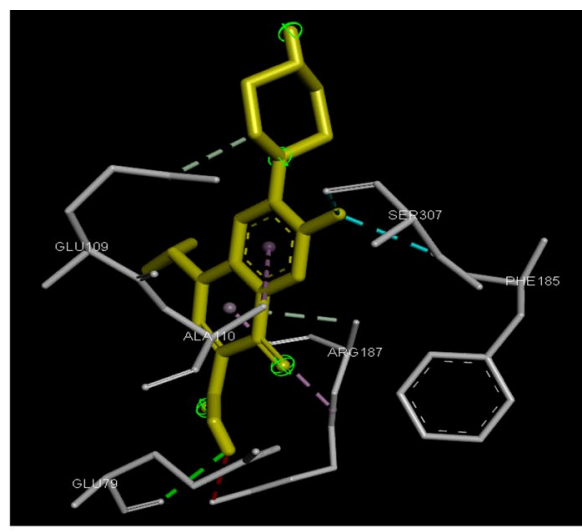

(b)

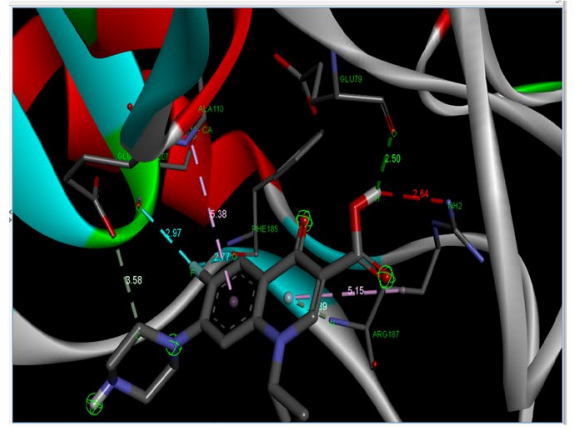

(d) et al. (2016a). This could be due to variation in ecological factors, climate, geographical location, time of harvesting and age of plants.

The rule of five has been established by Lipinski et al. (1997) to predict favourable ADME properties using computer models (Lipinski et al. 1997). For an active substance to be considered, it should not violate more than two of the rule of five: Molecular weight $\leq 500$ Da, Partition coefficient $\log P \leq 5$, No more than $5 \mathrm{H}$-bond donor groups, No more than $10 \mathrm{H}$-bond acceptor groups. These simple rules (as a factor of five) were derived from experience and are almost exclusively used to preselect compounds for screening. Usually, the more lipophilic a compound is, the better it will be absorbed and consequently, the stronger the biological activity; however, limited solubility in the aqueous phase restricts lipophilicity. Relevant test models have been developed by using thin layers of human colon carcinomas (Caco2). These also allow the absorption by transporters to be studied. As we see in our study (in Table 2), the lipophilicity values correspond to the $\mathrm{Caco} 2$ values and varies directly with human intestinal absorption values. These three parameters are observed to work in tandem; an increase in one predicts an increase in the other. However, we see that lipophilicity again correlates negatively with water solubility as seen with b-D-glucopyranose with $\log P=-3.2214$, water solubility $=-1.377$, $\operatorname{caco} 2=0.249$ and human intestinal absorption $=21.51$, which is the lowest among all the profiled ligands absorption prediction. Caco 2 permeability and human intestinal absorption (HIA) indices are factors that determine the ultimate bioavailability of the drug.

Another system that was recently structurally characterized is the membrane-bound glycoprotein GP170, an efflux membrane transporter and a member of the ATP-binding cassette transporter found primarily in epithelial cells. It is a transporter that can expel drugs from the cell. Our study (Table 2) shows that quindoline and ciprofloxacin are substrates of P-glycoprotein and therefore can modulate the physiological functions of P-glycoprotein by regulating the active uptake and the distribution of drugs. Hydrophilic substances and polar metabolites, including those after conjugation with polar groups, are excreted via the kidneys. The excretion of lipophilic substance is usually accomplished hepatically, and subsequently over the intestines. Such substances often undergo oxidative metabolism, with the concomitant possibility of toxic metabolites being produced (Klebe 2013).

The predicted toxicity effect of the drug on Salmonella typhimurium reverse mutation assay showed that quindoline and 2-methoxyl-4-vinylglycine could trigger mutagenic events while others are considered as non-mutagenic agents. However, the toxicities of all the extremely lipophilic ligands in Tetrahymena pyriformis were high ranging from 0.545 to 


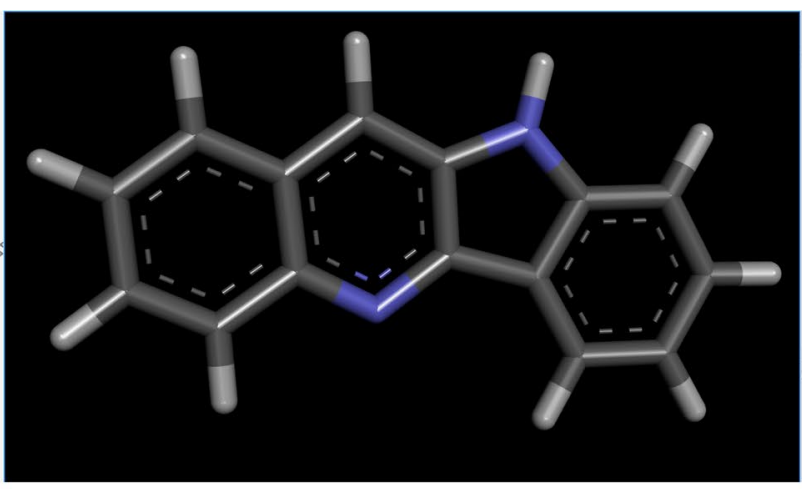

(a) Quindoline

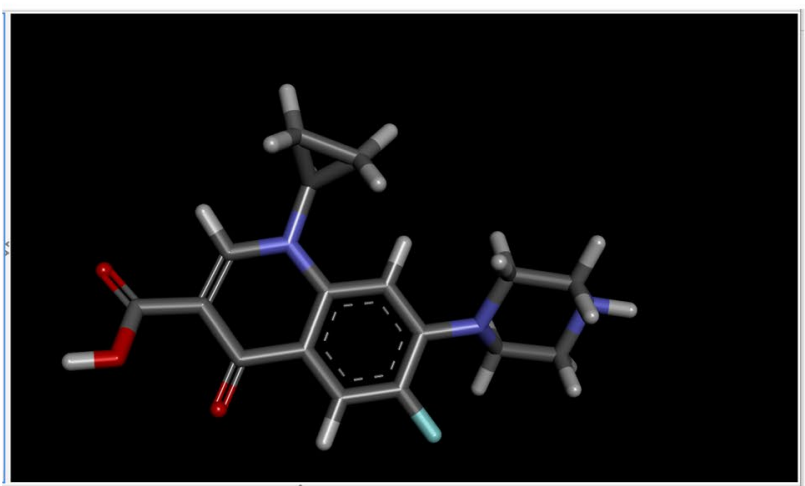

(b) Ciprofloxacin

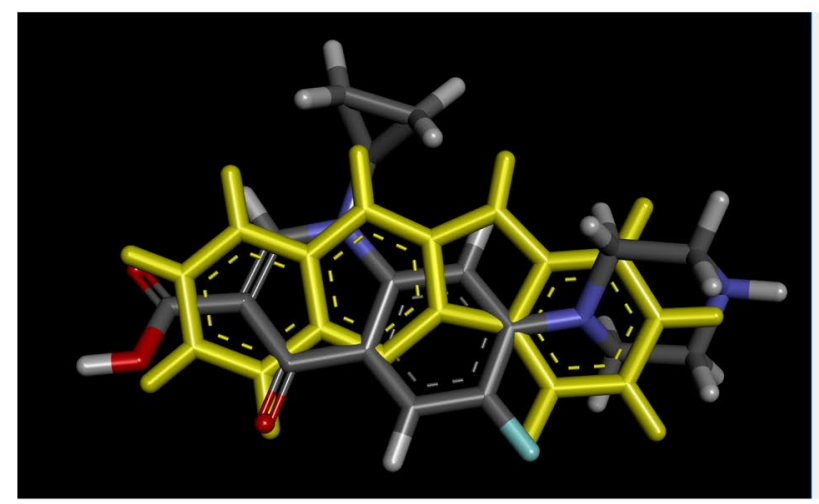

(c) Superimposition of Quindoline (yellow) on ciprofloxacin (dark)

Fig. 11: 3D structure of a quindoline $\mathbf{b}$ ciprofloxacin and $\mathbf{c}$ Superimposition of Quindoline (yellow) on ciprofloxacin

1.884, while 2-methoxyl-4-vinylglycine showed the highest toxicity level of all the ligands with a concentration of $0.071 \mathrm{ug} / \mathrm{l}$. Also, these extremely lipophilic ligands namely: 8,11,14-eicosatrienoic acid, 9,12,15-octadecatrienoic acid, bis (2-ethylhexyl) phthalate and phytol induced minnow toxicity with concentrations as low as $-1.665,-1.183,-2.266$ and $-1.504 \mathrm{nM}$ respectively, indicating high cytotoxic effects of the ligands, hence confirming their possible lethal effects on cells. Bis (2-ethylhexyl) phthalate has been linked to increased incidence of hepatocellular carcinomas in animals by the National cancer institute with primary routes of exposure such as inhalation, digestion and dermal contact According to Adeoye et al. (2020), the acute toxicity of a ligand/drug predicts it possible toxicity effects, either mild or severe which could occur within a short time-frame after administration (Adeoye et al. 2020). Quindoline, 1,2,3-benzetriol, 8,11,14-eicosatrienoic acid and 9,12,15-octadecatrienoic acid were shown to elicit a low maximum tolerated dose in humans.

Another large group of enzymes worthy of mention are the cytochrome P450 (CYPs) metabolic enzymes. CYPs are the major enzymes involved in drug metabolism. They account for approximately $75 \%$ of the total metabolic activity taking place in the organism. Consequently, most drugs undergo deactivation by CYPs, either directly or by facilitated excretion from the body. Also, many substances are biotransformation by CYPs to form their active compounds (Chatterjee and Franklin 2003). Humans have 57 genes and more than 59 pseudogenes divided among 18 families of cytochrome P450 genes and 43 subfamilies. CYP 1, 2 and 3 are involved in drug and steroid metabolism. Our study reveals that Quindoline was predicted as the highest CYPs promiscuity by its ability to interact with 6 out of 7 available CYPs on virtual screening by acting as CYP3A4 substrate, CYP1A2 inhibitor, CYP2C19 inhibitor, CYP2C9 inhibitor, CYP2D6 inhibitor and CYP3A4 inhibitor. Ciprofloxacin, b-D-glucopyranose and 1,2,3-benzetriol did not show any interaction with CYPs, either by acting as a substrate or inhibitor as seen in Table 5. However, none of the ligands was predicted as a substrate for CYP2D6, which provides an open field for further study here. Many drugs have been observed to either increase or decrease the activity of various CYP isozymes either by inducing the biosynthesis of an isozyme or by inhibiting the activity of the CYP. This is a major source of adverse drug interactions, since changes in CYP enzyme activity may affect the metabolism and clearance of various drugs (Klebe 2013; Guengerich 2008).

Molecular interaction studies of quindoline binding pocket of HMG-CoA reveals that the inhibitor-enzyme relationship is primarily dominated by hydrogen bond and hydrophobic interactions. Panigrahi and Desiraju (2007) have provided comprehensive reports on the contribution of hydrogen bonds to binding affinity of a target-drug, and Patil et al.(2010) identified the relevance of hydrophobic interaction on target-drug (Panigrahi and Desiraju 2007; Patil et al. 2010). A hydrogen bond is characterized by a pronounced distance and angle dependence. It is directional and its geometry is defined within narrow limits. Because of their strength, hydrogen bond interactions are specific, with conserved orientation. However, they are also made and broken rapidly during complexation, conformational change, and folding. This study suggests that 
the high number of electrostatic hydrogen bond could be responsible for the highest binding affinity exhibited by Quindoline. As revealed by previous studies by Panigrahi and Desiraju (2007), the median $\mathrm{H}-\mathrm{O}$ distance, $\mathrm{d}$, in a ligand-protein interaction that may affect a ligand binding is $\leq 2.0 \mathrm{~A}^{\circ}$ and that the hydrogen bonds are linear, having set the standard $\mathrm{H}$-bonding criteria as $\mathrm{d}(\mathrm{H}-\mathrm{A}) \leq 3.0 \mathrm{~A}^{\circ}$ and $\Theta(X-\mathrm{H}-\mathrm{A}) \leq 90^{\circ}$ (Panigrahi and Desiraju 2007).

Hydrophobic interactions are created through the close proximity between non-polar amino acid side chains of the protein and lipophilic groups on the ligand. It should be noted that these lipophilic groups are aliphatic or aromatic hydrocarbon groups and halogen substituents (e.g., chlorine, fluorine) and other heterocycles (e.g. thiophene and furan). Usually, all areas that cannot form hydrogen bonds are counted as lipophilic parts of the surface of a protein and ligand. As shown in our study, hydrophobic interactions often afford a significant contribution to the binding affinity for ligands with large lipophilic groups: A:PHE236-:QUIN (pi-pi T-shaped hydrophobic bond, $\mathrm{d}=4.99 \mathrm{~A}^{0}$ ), QUIN-:PRO235:A (pi-aliky hydrophobic bond, $\mathrm{d}=5.43 \mathrm{~A}^{0}, 4.57 \mathrm{~A}^{0}, 4.29 \mathrm{~A}^{0}$ ). This might have further improved the activity of Quindoline. Teague et al. (1999) reported that the average number of hydrophobic atoms in marketed drugs is 16 , with one to two donors and three to four acceptors (Teague et al. 1999). Hence, we cannot fail to emphasize the importance of hydrophobic interactions in drug designing. Several studies have also revealed that increase in hydrophobic atoms in active site of drug-target interface further increases the biological activity of a drug-lead (Qian et al. 2007; Hansch and Leo and Taft RW 1991).

Other weak interactions involving halogen atom (both as electrophiles and nucleophiles), $\mathrm{p}$-acceptors and sulphur atom acceptors are also important in the protein-ligand interface. The presence of several pi-pi and pi-alkyl hydrophobic bond appear to affect the binding of quindoline to HMG-CoA. However, previous findings have predicted a distance of $d \leq 3.5 \mathrm{~A}^{\circ}$ and angle $\Theta \leq 100^{\circ}$. Hence, the distance exhibited by these weak interactions may not favour ligand binding. Furthermore, we observed in our study that $\mathrm{pi}-$ sulphur bond was found to be present, having a distance $\mathrm{d}$ of $5.81 \mathrm{~A}^{\mathrm{o}}$ and $5.21 \mathrm{~A}^{\mathrm{o}}$. Although, studies have shown that sulphur atoms are larger and have a more diffuse electron cloud than oxygen and nitrogen and they are still capable of participating in hydrogen bonds. However, a hydrogen bond is presumed to exist if the distance $\mathrm{d}(\mathrm{H}-\mathrm{S})$ is $\leq 2.9 \mathrm{~A}^{\circ}$.

\section{Declarations}

Ethical statement This article does not contain any studies involving animals performed by any of the authors. This article does not contain any studies involving human participants performed by any of the authors.

Conflict of interest The authors declare no conflict of interest.

\section{References}

Adeoye AO, Oso BJ, Olaoye IF, Tijani H, Adebayo AI (2020) Repurposing of chloroquine and some clinically approved antiviral drugs as effective therapeutics to prevent cellular entry and replication of coronavirus. J Biomol Struct Dyn. https://doi.org/10. 1080/07391102.2020.1765876

Akinpelu DA, Onakoya TM (2006) Antimicrobial activities of medicinal plants used in folklore remedies in South-western Nigeria. Afr J Biotech 5(11):1078-1081

Alwash MS, Ibrahim N, Ahmad WAY (2013) Identification and mode of action of antibacterial components from Melastoma malabathricum Linn leaves. Am J Infect Dis 9(2):46-58

Assob JC, Kamga HL, Nsagha DS, Njunda AL, Nde PF (2011) Antimicrobial and toxicological activities of five medicinal plant species from Cameroon traditional medicine. BMC Complement Altern Med 11:70

Awomukwu DA, Nyananyo BL, Onukwube ND, Uka CJ, Okeke CU, Ikpeama AI (2014) Comparative phytochemical constituents and pharmacognistic importance of the vegetative organs of some Phyllanthus species in South Eastern Nigeria. Int J Modern Bot 4(2):29-39

Boakye YD, Agyare C, Hensel A (2016a) Anti-infective properties and time-kill kinetics of phyllanthus muellerianus and its major constituent. Geraniin Med Chem 6(2):095-104

Boakye YD, Agyare C, Dapaah SO (2016b) in vitro and in vivo antioxidant properties of Phyllanthus muellerianus and its major constituent, geraniin. Oxid Antioxid Med Sci 5(2):1-9

Boakye YD, Agyare C, Abotsi WKM, Ayande PG, Ossei PPS (2016c) Anti -inflammatory activity of aqueous leaf extract of Phyllanthus muellerianus (Kuntze) Exell. and its major constituent, geraniin. J Ethnopharmacol 187:17-27

Chatterjee P, Franklin MR (2003) Human cytochrome p450 inhibition and metabolic-intermediate complex formation by goldenseal extract and its methylenedioxyphenyl components. Drug Metabol Dispos Biol Fate Chem 31(11):1391-1397

Clinical and Standard Laboratory Institute (CLSI) 2013. Performance standards for antimicrobial susceptibility testing. 27th edition: M02 - A12

Cushnie TP, Lamb AJ (2005) Antimicrobial activity of flavonoids. Int J Antimicrob Agents 26:343-356

Daina A, Michielin O, Zoete V (2017) SwissADME: a free web tool to evaluate pharmacokinetics, drug-likeness and medicinal chemistry friendliness of small molecules. Sci Rep 7:42717. https://doi.org/ $10.1038 /$ srep42717

DeLano WL (2002) The PyMOL molecular graphics system. Delano Scientific, San Carlos

Doughari JH, Sunday D (2008) Antibacterial activity of Phyllanthus muellerianus. Pharm Biol 46(6):400-405

European Committee on Antimicrobial Susceptibility Testing (EUCAST) 2018. Breakpoint tables for interpretation of MICs and zone diameters. Version 8.0, http://www.eucast.org

Eweas AF, Maghrabi IA, Namarneh AI (2014) Advances in molecular modeling and docking as a tool for modern drug discovery. Der Pharma Chemica 6(6):211-228

Fowler, D.G. 2006. Traditional fever remedies: a list of Zambian plants. Available at http://www.giftshealth.org/ritam/news/Traditiona 1Feverremedies1.pdf. Accessed on 17th September, 2017 
Guengerich FP (2008) Cytochrome p450 and chemical toxicology. Chem Res Toxicol 21(1):70-83. https://doi.org/10.1021/tx700 $079 \mathrm{z}$

Guo C, Yang J, Wei J, Li Y, Xu J, Jiang Y (2003) Antioxidant activities of peel, pulp and seed fractions of common fruits as determined by FRAP assay. Nutr Res 23:1719-1726

Gupta S, Kapoor P, Chaudhary K, Gautam A, Kumar R, Raghava GPS (2013) In silico approach for predicting toxicity of peptides and proteins. Open Sour Drug Discov Consort PLoS ONE 8(9):e73957. https://doi.org/10.1371/journal.pone.0073957

Hansch C, Leo A, Taft RW (1991) A survey of Hammett substituent constants and resonance and field parameters. Chem Rev 91:165-195

Isa MA, Mustapha A, Qazi S et al (2020) In silico molecular docking and molecular dynamic simulation of potential inhibitors of 3C-like main proteinase (3CLpro) from severe acute respiratory syndrome coronavirus-2 (SARS-CoV-2) using selected african medicinal plants. ADV TRADIT MED (ADTM). https://doi.org/ 10.1007/s13596-020-00523-w

Khan RA, Khan MR, Sahreen S, Ahmed M (2012) Assessment of flavonoids contents and in vitro antioxidant activity of Launaea procumbens. Chem Cent J 6:43

Kim D, Chin M, Yu H, Pan X, Bian H, Tan Q, Kahn RA, Tsigaridis K, Bauer SE, Takemura T, Pozzoli L, Bellouin N, Schulz M (2019) Asian and trans-Pacific Dust: a multi-model and multiremote sensing observation analysis. J Geophys Res Atmos 124(23):13534-13559. https://doi.org/10.1029/2019JD030822

Kitchen DB, Decornez H, Furr JR, Bajorath J (2004) Docking and scoring in virtual screening for drug discovery: methods and applications. Nat Rev Drug Discov 3(11):935-949. https://doi.org/10. 1038/nrd1549

Klebe G (2013) From in vitro to in vivo: optimization of ADME and toxicology properties. Drug Design. https://doi.org/10.1007/9783-642-17907-5_19

Lee LF, Mariappan V, Vellasamy KM, Vannajan SL, Vadivelu J (2016) Antimicrobial activity of Tachyplesin 1 against Burkholderia pseudomallei: an in vitro and in silico approach. Peer Journal 4:e2468. https://doi.org/10.7717/peerj.2468

Lipinski CA, Lombardo F, Dominy BW, Feeney PJ (1997) Experimental and computational approaches to estimate solubility and permeability in drug discovery and development settings. Adv Drug Deliv Rev 23(1-3):3-25. https://doi.org/10.1016/s0169409x(96)00423-1

Meda A, Lamien CE, Romito M, Millogo J, Nacoulma OG (2005) Determination of the total phenolic, flavonoid and proline contents in Burkina Fasan honey, as well as their radical scavenging activity. Food Chem 91:571-577

Miksusanti B, Laksmi J, Babang P, Priosoeryanto R, Rizal S, Gatot TR (2008) Mode of action of Temu kunci (Kaempferia pandurata) essential oil on E. coli K1.1 cell determined by leakage of material cell and salt tolerance assays. HAYATI J Biosci 15(2):56-60

Minussi RC, Rossi M, Bologna L, Cordi L, Rotilio D, Pastore GM, Duran N (2003) Phenolic compounds and total antioxidant potential of commercial wines. Food Chem 82:409-416

Odenholt I, Lowdin E, Cars O (2001) In vitro pharmacodynamics of telithromycin against respiratory tract pathogens. Antimicrob Agents Chemother 45:23-29
Oluwafemi F, Debiri F (2010) Antimicrobial effect of Phyllanthus amarus and Parquetina nigrescens on Salmonella typhi. Afr J Biomed Res 11:215-219

Panigrahi SK, Desiraju GR (2007) Strong and weak hydrogen bonds in the protein-ligand interface. Proteins 67:128-141. https://doi. org/10.1002/prot.21253

Patil A, Kinoshita K, Nakamura H (2010) Hub promiscuity in proteinprotein interaction networks. Int J Mol Sci 11(8):2791. https://doi. org/10.3390/ijms 11082791

Pires DEV, Blundell TL, Ascher DB (2015) pkCSM: predicting smallmolecule pharmacokinetic and toxicity properties using graphbased signatures. J Med Chem 58:4066-4072. https://doi.org/10. 1021/acs.jmedchem.5b00104

Qian X, He Y, Luo Y (2007) Binding of a second magnesium is required for ATPase activity of RadA from Methanococcus voltae. Biochemistry 46(20):5855-5863. https://doi.org/10.1021/ bi6024098

Rutala WA, Weber DJ (2013) Disinfection and sterilization. Am J Infect Control 41(5):S2-S3

Saleem M, Nazir M, Akhtar N, Onocha PA, Riaz N, Jabbar A, Sultana N (2009) New phthalates from Phyllanthus muellerianus (Euphorbiaceae). J Asian Nat Prod Res 11:974-977

Shon MY, Kim TH, Sung NJ (2003) Antioxidants and free radical scavenging activity of Phellinus baumii (Phellinus of Hymenochaetaceae) extracts. Food Chem 82:593-597

Siram S, Patel MA, Patel KV, Punjani NH (2004) Compendium on Medicinal Plants. Gujarat SA, ed Ahmedabad, India, Agricultural University, 1-54

Stojkovic DS, Zivkovic J, Sokovic' M, Glamoclija J, Ferreira ICFR, Jankovic' T, Maksimovic Z (2013) Antibacterial activity of Veronica montana L. extract and of protocatechuic acid incorporated in a food system. Food Chem Toxicol 55:209-213

Taylor RD, Jewsbury PJ, Essex JW (2002) A review of protein-small molecule docking methods. J Comput Aided Mol Des 16(3):151166. https://doi.org/10.1023/a:1020155510718 (PMID:12363215)

Teague SJ, Davis AM, Leeson PD, Oprea T (1999) The design of leadlike combinatorial libraries. Angew Chem Int Ed 38:37433748

Trott O, Olson AJ (2010) AutoDock Vina: improving the speed and accuracy of docking with a new scoring function, efficient optimization, and multithreading. J Comput Chem 31(2):455-461. https://doi.org/10.1002/jcc.21334

Yang JH, Tseng YH, Lee YL, Mau JL (2006) Antioxidant properties of methanolic extracts from monascal rice. Food Sci Technol 39:740-747

Zhao SB, Wang S (2010) Luminescence and reactivity of 7-azaindole derivatives and complexes. Chem Soc Rev 39(8):3142-3156. https://doi.org/10.1039/c001897j (Epub2010Jun 24 PMID: 20577664)

Publisher's Note Springer Nature remains neutral with regard to jurisdictional claims in published maps and institutional affiliations. 